\title{
Windbreak Designs and Planting for Florida Agricultural Fields ${ }^{1}$
}

\author{
Bijay Tamang, Michael G. Andreu, Melissa H. Friedman, and Donald L. Rockwood²
}

A well-designed and properly planted windbreak can reduce soil erosion and crop damage and provide many other benefits (for more information on windbreak benefits, refer to EDIS publication FOR192 at http://edis.ifas.ufl.edu/FR253), but establishing a windbreak can also be challenging and time consuming. In order to ensure that the implementation process goes smoothly and the windbreak functions as desired, it is necessary to prepare in advance. This publication reviews several design and planting options in order to assist in windbreak planning and development.

Before planting, consider windbreak orientation, height, length, and porosity. Would a single row or multiple rows of trees work best? How much space should you leave within and between rows? What porosity is best for your purposes? Planning a windbreak requires the consideration of all of these factors, which are influenced by the species that make up the windbreak (species information can be obtained in EDIS publication FOR224:

http://edis.ifas.ufl.edu/FR286) and site conditions where they will be planted. Overall, a windbreak should maximize landowner goals and objectives.

\section{Considerations for Windbreak Design:}

\section{a. Orientation}

Before establishing windbreaks, one should have a good idea of the prevailing wind direction. Windbreaks are most effective when the orientation is perpendicular to the prevailing wind (Tamang et al. 2008). If planted perpendicular to the wind, a single-leg windbreak tends to provide protection on the leeward side (the side sheltered from the wind) in the shape of a triangle (Figure 1a). For areas where the dominant winds blow from more than one direction, it is best to plant a windbreak with multiple legs in order to provide adequate crop and soil protection (Figure 1b). Where wind direction is highly variable, plant a leg on each side of the field to enclose the area.

\section{b. Height}

The height of the dominant trees determines the extent of the area protected on the leeward side of a windbreak. A good rule of thumb is that a windbreak will reduce wind to a distance of about 10 times the windbreak height, although this distance can

1. This document is FOR227, one of a series of the School of Forest Resources and Conservation Department, Florida Cooperative Extension Service, Institute of Food and Agricultural Sciences, University of Florida. Original publication date August 2009. Visit the EDIS Web Site at http://edis.ifas.ufl.edu.

2. Bijay Tamang, graduate student; Michael G. Andreu, assistant professor; Melissa H. Friedman, biological scientist; and Donald L. Rockwood, professor, School of Forest Resources and Conservation, IFAS, University of Florida

The Institute of Food and Agricultural Sciences (IFAS) is an Equal Opportunity Institution authorized to provide research, educational information and other services only to individuals and institutions that function with non-discrimination with respect to race, creed, color, religion, age, disability, sex, sexual orientation, marital status, national origin, political opinions or affiliations. U.S. Department of Agriculture, Cooperative Extension Service, University of Florida, IFAS, Florida A. \& M. University Cooperative Extension Program, and Boards of County Commissioners Cooperating. Millie FerrerChancy, Interim Dean 


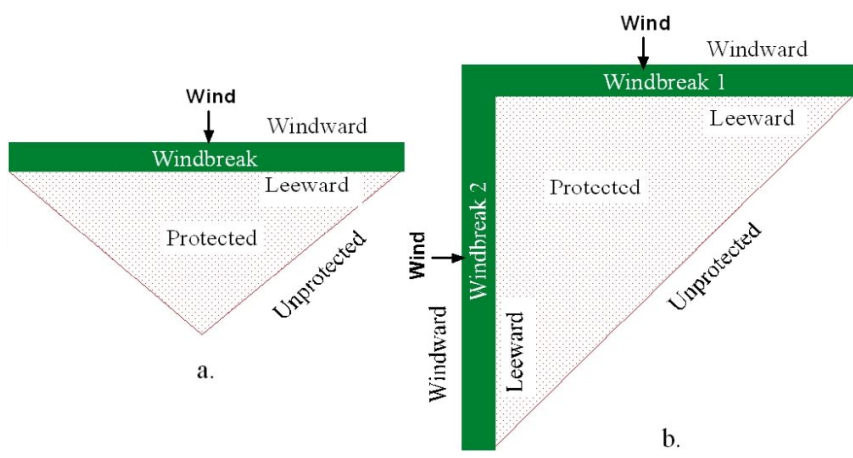

Figure 1. Area of protection behind a single leg windbreak (a) and two-leg windbreaks perpendicular to each other (b). Credits: Bijay Tamang

sometimes extend to 30 times the windbreak height (Cleugh et al. 2002). For example, if the trees are 20 feet tall, a windbreak can be expected to reduce wind up to 200 feet from the trees. In a multiple-row windbreak, the tallest row usually determines the extent of the area being protected (Figure 2).

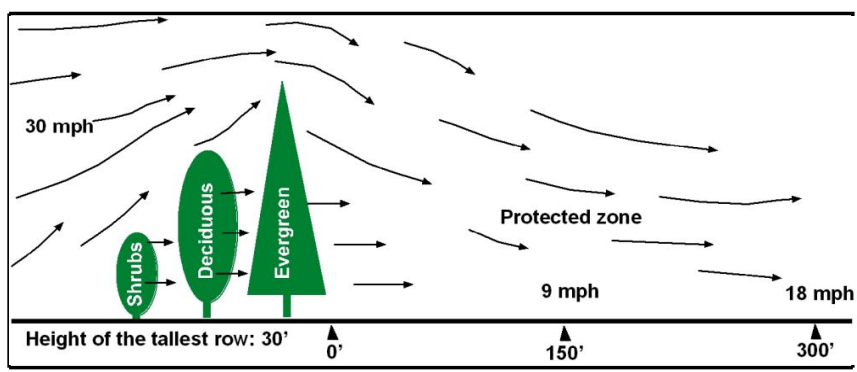

Figure 2. Effect of height on the amount of protected area behind the windbreak. Credits: Bijay Tamang

\section{c. Porosity}

Porosity is the ratio of the open portion of the windbreak (where stems, branches, or leaves are missing) to its total volume. For practical purposes, windbreak porosity can be considered equivalent to optical porosity, which is the percentage of open space you see when you stand directly in front of the windbreak (Straight and Brandle 2007). The more porous the windbreak is, the more wind can pass through it. Windbreaks that allow some wind to pass through them are more effective, as this decreases the potential for turbulence to develop on the leeward side of the windbreak. As the porosity decreases, the strength of turbulence increases (Figure 3); leading to soil erosion and other adverse effects. Strong turbulence damages crops near the windbreak and decreases the area protected.
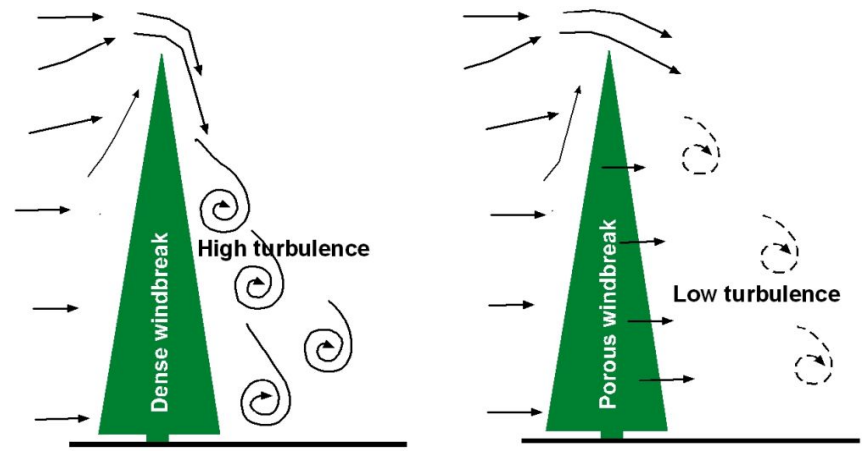

Figure 3. Effect of porosity on wind turbulence on the leeward side of the windbreak. Windbreaks that do not allow wind to penetrate through them create high levels of turbulence on the leeward side while windbreaks that allow some wind to penetrate through them create less turbulence on the leeward side. Credits: Bijay Tamang

If a single row windbreak is not porous enough, it simply acts as a solid barrier which is problematic as this creates turbulence on the windward side of the windbreak. To avoid this problem, plant species in several rows in order of increasing height from the outside of the windbreak to the inside of the windbreak. Then, as wind hits the windbreak, it will be deflected upwards, reducing turbulence and damage to crops (Figure 4).

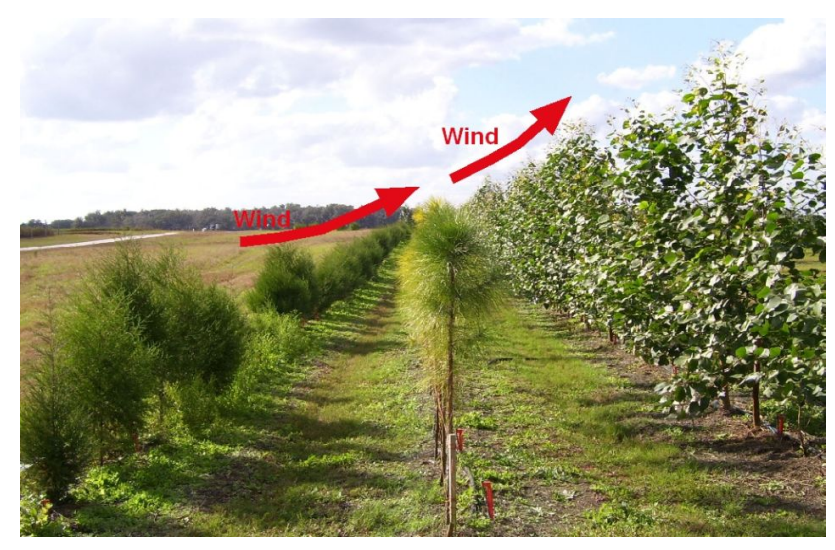

Figure 4. Impact of a multiple-row windbreak on the movement of wind. As wind moves from the shorter outer row to taller inner row, the wind is deflected upwards. Credits: Bijay Tamang

For best results, porosity should be uniformly distributed throughout the windbreak. The recommended porosity for crop and soil protection should be between 40-60 percent, but porosity above 60 percent is more effective for protecting structures and livestock, or when you're using the windbreak as a privacy screen. Adjust porosity by selecting the appropriate species, the number of rows, and the 
spacing between the trees within each row. An evergreen species such as eastern redcedar (Juniperus virginiana), has a crown that extends down to the ground. This kind of crown provides year-round uniform porosity. If such a species is used, a single-row windbreak may be sufficient for effective protection (Figure 5). When species with less crown length are used, shorter trees or shrubs can be planted in another row to cover the void at the bottom of the windbreak.

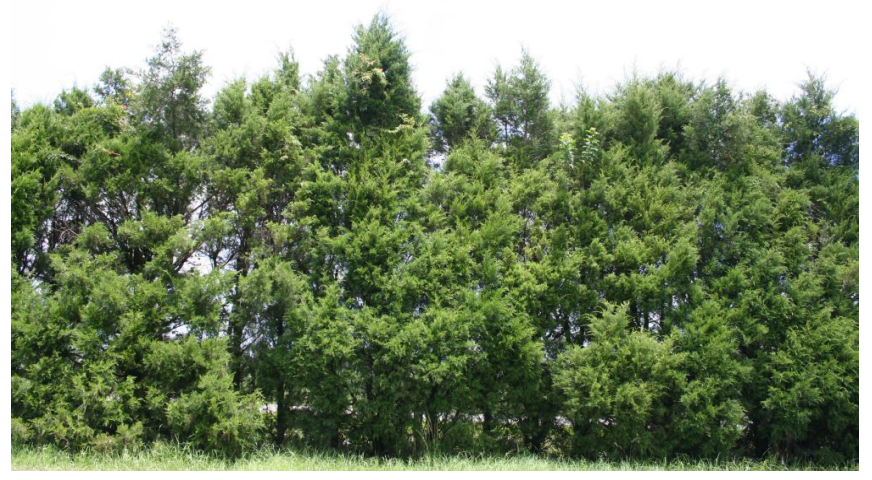

Figure 5. Twenty-year-old (22-foot-tall) single-row eastern redcedar windbreak at Southwest Florida Research and Education Center, Immokalee, Florida. Credits: Bijay Tamang

\section{d. Length}

The total length of a windbreak leg determines the amount of area protected behind the windbreak. Long and continuous rows are usually preferred for greater area protection. If you need a gap in a multiple-row windbreak for road access or some other reason, make an angled cut rather than a straight cut through the windbreak in order to prevent wind speed from increasing through the gap (Figure 6). The low pressure on the leeward sides of the windbreak causes wind to curve in around the ends of the windbreak. Windbreaks therefore should be longer than the length of the field that needs protection. Generally, the preferred windbreak length is at least 10 times the windbreak maximum height, but this will vary depending on the size of the area that needs protection.

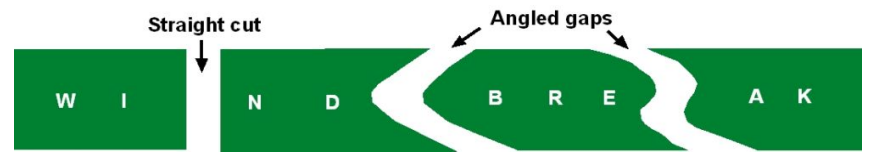

Figure 6. Potential gap designs in a multiple-row windbreak. Credits: Bijay Tamang

\section{Considerations for Windbreak Planting:}

Windbreak planting is a critical step in the process of establishing a windbreak. Take care to choose good quality trees. Guidelines for planting trees can be found in EDIS document CIR759: http://edis.ifas.ufl.edu/FR024.

\section{a. Number of rows}

The basic requirement of a windbreak is to have a continuous row of trees or shrubs with uniform porosity and height. The number of rows in a windbreak is usually determined by financial constraints, available space and seedlings, and species selected (for more information about which species to use in a windbreak, refer to EDIS publication FOR224: http://edis.ifas.ufl.edu/FR286). If your space is limited, you could plant a single row of evergreen species, but it is usually difficult to get the desired porosity from a single-row windbreak, so when enough space and seedlings are available, plant multiple-row windbreaks. Planting a few rows of trees will help achieve the right porosity, and it can prevent damage from turbulence on the leeward side of the windbreak. If you use deciduous species, then plant multiple rows in combination with evergreen species for optimum results. Planting several rows can also create opportunities to generate income by harvesting some of the windbreak for timber or other wood products without affecting its viability.

1. Single-row windbreaks: Use a single-row windbreak when space is limited. This type of windbreak is made up of a continuous row of trees and/or shrubs at a fixed spacing. If the tree species is evergreen and densely foliated with branches extending down to the base of the tree, a single-row windbreak may be sufficient for adequate protection. In other cases, shrubs can also be planted alternately with the trees to cover the lower portion of the trunk that is generally free of foliage. 
2. Multiple-row windbreaks: Combinations of one or more rows of trees and shrubs can be planted in different configurations to meet the desired porosity in multiple-row windbreaks (Figure 7a \& b). Rather than adopting a regular planting design as in Figure 7a, you can reduce porosity by adopting an offset row design as in Figure 7b. As wind moves from the first row to the second, the tree in the second row also acts as barrier to the wind penetrating the field. Unless you use correct planting configurations and species combinations, you may not achieve the porosity you need even from multiple-row windbreaks (Figure 8). Regardless of how rows are configured, the tallest species should be planted on the leeward side and the shortest species on the windward side, with species of intermediate height in between.

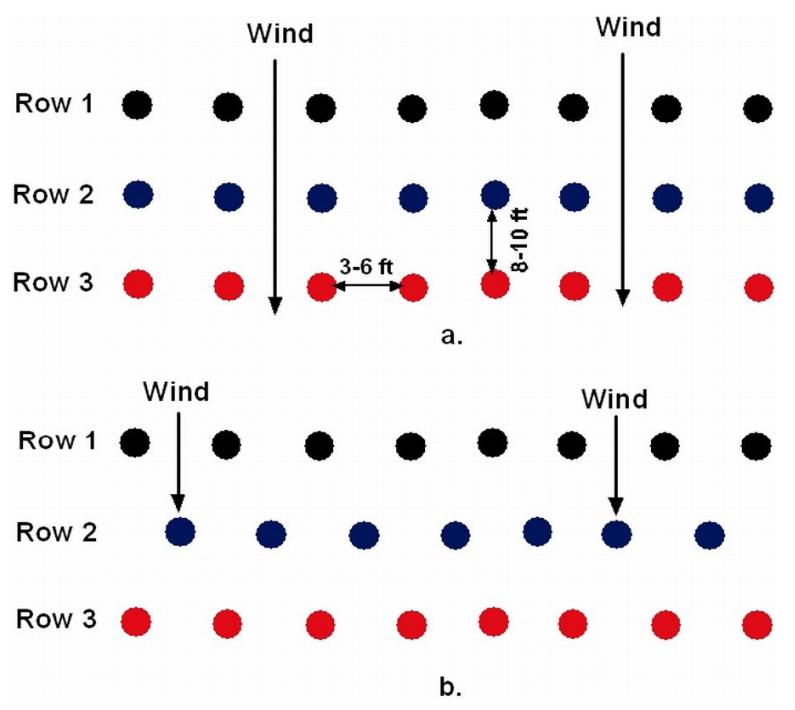

Figure 7. Planting configurations in a multiple-row windbreak; colors represent different species. (a) A three-row windbreak design in a regular row arrangement and (b) a three-row windbreak design with second row offset. Credits: Bijay Tamang

\section{b. Row spacing}

Spacing between rows within a windbreak should be based on tree and shrub growth habits, local conditions, and available land. Spacing between and within rows is usually guided by the expected crown spread and the type of equipment you'll use in the maintenance and management of the windbreak (e.g. tractors, mowers). Ideal spacing for potential windbreak species can be found in the EDIS document FOR224: http://edis.ifas.ufl.edu/FR286

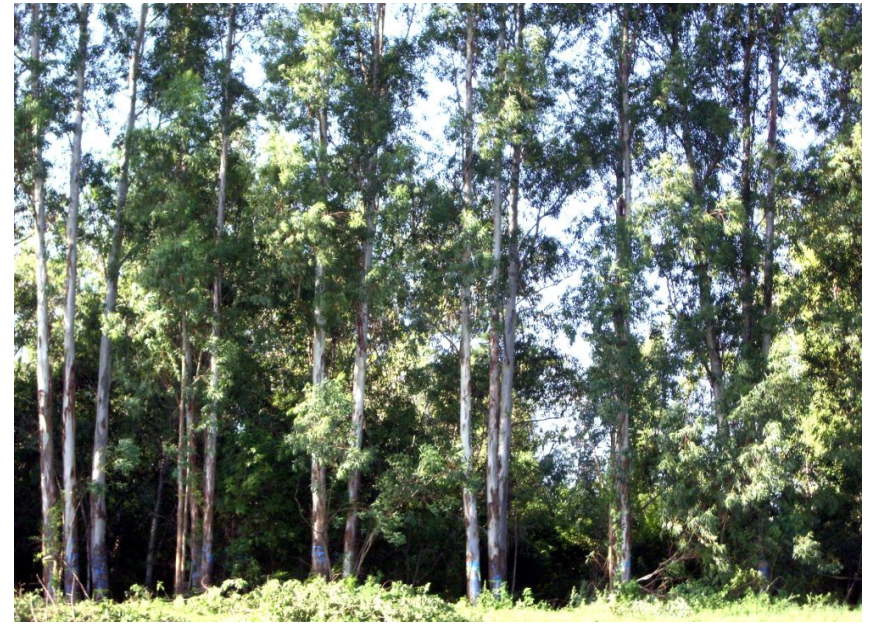

Figure 8. Three-row Eucalyptus grandis (near side) planted in a regular row design as in Figure 7a. The lower portion of the trees lack branches and leaves, creating a very porous windbreak. Adopting an offset row design as in Figure $7 \mathrm{~b}$ and incorporating a shrub or shorter tree row will reduce porosity. Credits: Bijay Tamang

\section{c. Seedling selection}

Choose good quality seedlings of similar size as much as possible. Seedlings should be locally grown or chosen from a nursery that grows species from an area with a climate similar to that in your planting area. Some seedlings should be set aside in a holding bed or potted to replace dead trees later. Both bare-root and potted seedlings can be used. Bare-root seedlings are cheaper, but seedling survival and growth may be compromised. Commercially available root gels can be used (e.g. Viterra Root-Dip) to keep roots moist and minimize stress and mortality while transporting and planting bare-root seedlings. Broadleaf and conifer seedlings should be 12 to 24 inches and 8 to 12 inches tall, respectively, and have healthy root systems (Boehner et al. 1992).

The area to be planted should be prepped before the seedlings arrive onsite. If the seedlings arrive early, keep them cool and keep the roots moist while preparing the planting area. Bare-root seedlings are best stored in a cooler, but if a cooler is not available dig a trench and bury the roots in the trench. In such cases pack the soil firmly and water it thoroughly so that all roots are fully immersed in moist soil. 


\section{d. Planting}

It is important to plan ahead and stake the position of each tree in a windbreak area for uniform spacing (Figure 9). In dry regions, the planting area for the windbreak should be left fallow for about a year to allow for moisture retention. Dig the holes for bare-root seedlings deeply enough to cover seedling roots and be careful not to expose the roots to the air for too long during planting to keep them from drying out. If you use potted seedlings, avoid removing them from their pots before their planting holes are ready. In dry conditions, you may need to water the planting hole before you plant. After the seedling is in the ground, pack the soil firmly to remove any air spaces in the planting hole and water each seedling, even if you added water to the planting hole before planting. For further information on irrigation and keeping the windbreak in good condition, refer to EDIS publication FOR228 (http://edis.ifas.ufl.edu/FR290).

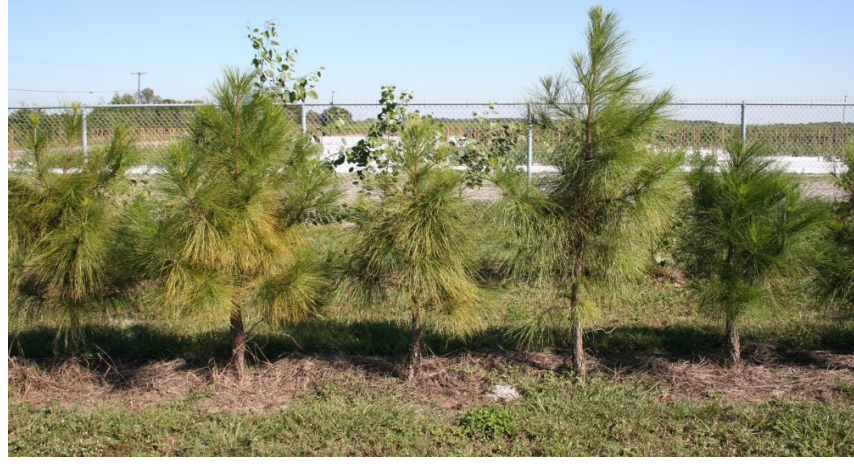

Figure 9. Uniform spacing in a windbreak at Gulf Coast Research and Education Center (UF), Balm, Florida. Credits: Bijay Tamang

\section{Conclusion}

Some forethought and care at the design and planting stages will allow you to maximize the benefits of windbreaks for your Florida agricultural fields. Adopting suitable windbreak designs will produce effective windbreaks that can modify microclimate and increase farm products. Some seedlings will die even under the best conditions, but good planning and advance preparation can increase the chances of seedling survival and minimize replanting costs.

\section{References:}

Andreu, M.G., B. Tamang, M.H. Friedman, and D.L. Rockwood. 2009. The benefits of windbreaks for Florida growers. FOR192. Gainesville: University of Florida Institute of Food and Agricultural Sciences. Retrieved August 14, 2009 from http://edis.ifas.ufl.edu/FR253.

Andreu, M.G., B. Tamang, D.L. Rockwood, and M.H. Friedman. 2009. Potential woody species and species attributes for windbreaks in Florida. FOR224. Gainesville: University of Florida Institute of Food and Agricultural Sciences. Retrieved August 14, 2009 from http://edis.ifas.ufl.edu/FR286.

Boehner, P., J. R. Brandle and S. Finch. 1992. Windbreak establishment. Technical Notes (Forestry No. 26). USDA Soil Conservation Service, June 1992, ftp://ftp-fc.sc.egov.usda.gov/OR/Technical_Notes/ Forestry/Forestry26.pdf

Cleugh, H., R. Prinsley, R.P Bird, S.J. Brooks, P.S. Carberry, M.C. Crawford, T.T. Jackson, H. Meinke, S.J. Mylius, I.K. Nuberg, R.A. Sudmeyer and A.J. Wright. 2002. The Australian National Windbreaks Program: overview and summary of results. Australian Journal of Experimental Agriculture 42: 649-664.

Duryea, M.L. 2000. Forest regeneration methods: natural regeneration, direct seeding, and planting. CIR759. Gainesville: University of Florida Institute of Food and Agricultural Sciences.

Retrieved August 14, 2009 from http://edis.ifas.ufl.edu/FR253.

Straight, R. and J. Brandle. 2007. Windbreak density: rules of thumb for design. Agroforestry Notes 36, USDA National Agroforestry Center, September 2007, http://www.unl.edu/nac/agroforestrynotes/ an36w03.pdf

Tamang, B., M.G. Andreu and D.L. Rockwood. 2008. Sustaining farm productivity through windbreaks. FAO Asia-Pasific Agroforestry Newsletter 33: 7-9. 
Tamang, B., M.G. Andreu, M.H. Friedman, and

D.L. Rockwood. 2009. Management of field

windbreaks. FOR228. Gainesville: University of

Florida Institute of Food and Agricultural Sciences.

http://edis.ifas.ufl.edu/FR290 